諈座「食品研究にナくに役立つ緒計姏理法」

(4)

\author{
パターン類似率とその応用 \\ 一食品研究におけるパターン解析一
}

田村真八郎・鈴木忠直・松 永隆司

（農林水産省 食品総合研究所）

一般に研究においては測定が行なわれる。多数の測定 対象について多数の測定項目がある場合は，特定の測定 項目の大小を諭ずるだけではなく，多数の測定項目の測 定値が構成する数值群パーンンんいて測定対象間の類 似，非類似などに関する情報が必要になる場合が多い。 成分含量については，ガスクロマトグラフィー，液体ク ロマトグラフィーなどで測定する場合はこのような情況 になる。

従来このような場合には，測定した数值群もしくはそ のヒストグラムを観察して直観的に類似, 非類似の判断 をするのが普通である。本稿で以下に解説するのは，数 値群ハターンの類似，非類似を計算して客観的な数值と して示し，直観的な判断を補強するのに有用なパターン 類似率の考え方およびその応用である。

ハターン類似率の概念は食品のアミノ酸パターンの研 究における必要性から導入”されたものであるが，フミ ，酸バターンはるちろん，有機酸，脂肪酸，色素，糖，

無譏質などの低分子の構成成分のパターンでも，また蛋 白質, 筑粉などの高分子の構成成分でも,さらには明確 な化学成分でなく，食品構成粒子の形，大きさ，比重な ぞによる分別成分の構成するパターンでるすぺて応用可 能である。特に鑑別，診断，分類なとの総合的判断が必 要な研究の場合にはきわめて有用な手法である。

1. パターンについて

パターンとは何か, パターン認識とは何か，パターン は先鍳的に存在するか否か，などに関しては松永らの解 説「成分パターンとパターン類似率」るを参照されたい が,ここでは最もパターン認識らしいものとして写真に よる人物判定を考えてみる。写真の大小にかかわらず人 物認識が可能なことから，バターンを構成する各部分,

つまり目，鼻，口などの大きさそのあのが変わっても相 互の比率が変わらなければ, パターンは変わらないと考
えてもよいであろら。それからの単純な類推で, 今一群 の数值から構成される数值群ハターンの場合, パターン の意味を，パターンを構成する各湘定項目の数値相互の 間の比率の総体であると考えてみよう。

すると, $n$ 個の測定項目の数値からなる二つの数值群 パターン $A ;\left(a_{1}, a_{2}, \ldots, a_{n}\right)$ とパターン $B ;\left(b_{1}, b_{2}\right.$, $\left.\ldots, b_{n}\right)$ とが同一パターンであるといらことは $a_{1}: a_{2}: \ldots: a_{n}=b_{1}: b_{2}: \ldots: b_{n}$

したがって，数値群 $A$ と数値群 $B$ とをそれぞれ，O を原点とする $\mathrm{n}$ 次元空間の位置べクトル $\overrightarrow{O A}, \overrightarrow{O B}$ の成 分表示と考えれば，ベクトル $\overrightarrow{O A}$ とべクト $\overrightarrow{O B}$ との 万向（向きも含める）が一致することは明らかである。 そこで $\mathrm{n}$ 個の数值よりなる数値群パターンを $\mathrm{n}$ 次元空 間内の位置べクトルの方向ととらえることにすると, 以 下の上らなパターンの計算法が考えられる3゙。

\section{2. パターン類似率}

数值群パターン $A$ と $B$ とが一致する場合は、べ トル $\overrightarrow{O A}$ と $\overrightarrow{O B}$ との方向が一致し, パターンの差異が 大きくなれば， $\overrightarrow{O A}$ と $\overrightarrow{O B}$ との作る角度が大きくなると 考えられるから， $\overrightarrow{O A}$ 之 $\overrightarrow{O B}$ の作万角度 $(\theta)$, もしくは その関数を用いて，パターンの類似性あるいは異質性を 数值として計算することができる。

実際に考えられるものとしては，パターン間距離 $(\theta$, ラージフンまたは度)，パターン異質率 $(\sin \theta)$ ，パター 類似率 $(\cos \theta)$ であるが，計算の簡便さ，得られる数 值のわかりやすさから，パターン類似率から始めるのが 実用的である。

そこで，数值群ハターン $A$; $\left(a_{1}, a_{2}, \ldots, a_{n}\right)$ とパ ターン $B ;\left(b_{1}, b_{2}, \ldots b_{n}\right)$ との間のパターン類似率を $S_{(A, B)}$ と書くとすれば, ベクトルの内積の公式

$(\overrightarrow{O A}, \overrightarrow{O B})=|\overrightarrow{O A}||\overrightarrow{O B}| \cos \theta=\sum_{i=1}^{n} a_{i} b_{i}$ 
から

$$
S_{(A, B)}=\cos \theta=\frac{(\overrightarrow{O A}, \overrightarrow{O B})}{|\overrightarrow{O A}||\overrightarrow{O B}|}=\frac{\sum_{i=1}^{n} a_{i} b_{i}}{\sqrt{\sum_{i=1}^{n} a_{i}{ }^{2}} \sqrt{\sum_{i=1}^{n} b_{i}{ }^{2}}}
$$

となる。

パターン類似率は，バターンが同一の場合は， $\theta=0$, したがって $S_{(A, B)}=\cos 0^{\circ}=1$ ，また $A$ と $B$ とが共通 の成分を全く含まないときは, $\theta=90^{\circ}, S_{(A, B)}=\cos 90^{\circ}$ $=0$ で，1から0までの間の数値となり，パターンが似 ているはと 1 に近い数値, 例えば 0.999 となり, 直感的 にわかりやすい。

\section{3. 遊離アミノ酸パターンの実例}

説明のために，果実・野菜の遊離アミノ酸パターンK 応用した例を，鈴木らの報告4)らから引用しよう。果実・ 野菜およびその加工品 135 点の分析結果の中から, 12 点
の測定值を拔すいして示したのが表 1，ヒストグラムで 因示したのが図 1 である。

従来は，表 1扰よび図1を観察することにより，トマ トとトマトシュースは似ているとか，デラウェアとトマ トは似ていないとかの判断を下すのであるが，数值計算 なしでの観察のみでは詳細な判断は困難である。そこで 12 対象間の遊離了ミノ酸バターンの類似性を数值化し て示すために, 12 食品間の ペターン類似率を前の式に したがって計算，表にしたのが表 2 のパターン類似率表 である。

パターン類似率表は，左上から右下へかけての対角線 を軸にして対称になっており，それぞれの食品の行と列 とが交わるところに，2食品間のパターン類似率が示さ れている。また対角線の部分はすべて同一食品どうしの 類似率であるから，全部1になるのであるが，これ恃省

表 1 果実・野菜 12 試料の遊離アミノ酸含量

$(\mathrm{mg} / 100 \mathrm{~g})$

\begin{tabular}{|c|c|c|c|c|c|c|c|c|c|c|c|c|}
\hline \multirow[b]{2}{*}{ アミノ酸 } & \multicolumn{3}{|c|}{ カンキツ } & \multicolumn{3}{|c|}{ リン ゴ } & \multicolumn{3}{|c|}{ ブドウ } & \multicolumn{3}{|c|}{$r>r$} \\
\hline & $\stackrel{\text { 温カ州 }}{ミ}$ & $\begin{array}{l}\text { ハッサ } \\
ク \\
\text { オレン } \\
\forall\end{array}$ & $\begin{array}{l}\text { グレー } \\
\text { プ } \\
\text { フルー } \\
ッ\end{array}$ & 陸 奥 & 国 光 & $\begin{array}{l}\text { ゴール } \\
\text { デン } \\
\text { デリシ } \\
+ス\end{array}$ & $\begin{array}{l}\text { デラウ } \\
\text { ×ア }\end{array}$ & 巨 峰 & $\begin{array}{l}\text { ネオマ } \\
\text { スカッ } \\
\text { ト }\end{array}$ & トマト & $\begin{array}{l}\text { トト } \\
\forall=- \\
\text { ス }\end{array}$ & 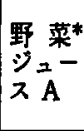 \\
\hline アスパラギン & 29.1 & 128.8 & 82.3 & 11.2 & 33.8 & 25.1 & 2.2 & 1.0 & 1.5 & 22.7 & 32.8 & 59.4 \\
\hline グルタ ミン & 9.1 & 11.5 & 7.8 & 0.5 & 0.5 & & 33.5 & 82.5 & 23.1 & 93.6 & 136.2 & 211.6 \\
\hline アスパラギン酸 & 24.3 & 22.1 & 63.1 & 2.9 & 8.1 & 9.9 & 4.8 & 6.1 & 2.9 & 24.0 & 57.3 & 45.5 \\
\hline スレオ & 2.6 & 2.9 & 3.6 & 0.2 & & + & 8.6 & 8.1 & 2.7 & 5.5 & 8.1 & 8.1 \\
\hline セ & 13.0 & 13.1 & 19.6 & 0.7 & 1.1 & 2.2 & 5.3 & 14.9 & 2.4 & 7.8 & 9.2 & 11.6 \\
\hline グルタ ミン酸 & 10.3 & 16.8 & 24.0 & 2.2 & 3.1 & 5.4 & 11.8 & 16.6 & 6.1 & 106.1 & 189.4 & 108.6 \\
\hline プ ロ & 16.2 & 85.9 & 79.7 & & & & 34.6 & 19.2 & 13.5 & & & \\
\hline グ リ & 0.8 & 1.3 & 2.8 & & & + & 1.0 & 1.5 & 0.5 & 1.1 & 1.4 & 1.6 \\
\hline ア ラ 二 & 11.1 & 20.1 & 18.1 & 1.0 & 0.9 & 0.6 & 72.1 & 55.7 & 11.0 & 4.1 & 8.1 & 17.5 \\
\hline ハ & 1.1 & 1.9 & 3.5 & & 0.4 & + & 4.3 & 4.1 & 1.3 & 3.2 & 2.3 & 3.3 \\
\hline イソロイシン & 0.4 & 0.5 & 1.1 & & 0.2 & + & 1.4 & 1.7 & + & 3.7 & 3.2 & 4.9 \\
\hline 口 1 シ & 0.4 & 0.4 & 1.0 & & & + & 3.5 & 2.7 & 0.6 & 3.7 & 3.0 & 3.7 \\
\hline 千 口 シ ソ & 0.8 & + & 1.5 & & & & 4.7 & 1.9 & 1.2 & 3.5 & 4.6 & 5.0 \\
\hline フェニルアラニン & 2.0 & 1.8 & 2.8 & & & & 3.3 & 3.9 & 1.2 & 10.6 & 12.3 & 12.2 . \\
\hline$r-\boldsymbol{\gamma} \leqslant$ ， 酪 酸 & 33.3 & 14.6 & 46.1 & & 1.5 & 0.7 & 19.9 & 7.4 & 7.7 & 62.3 & 52.1 & 47.6 \\
\hline オ & & 0.7 & 0.6 & & & & & 0.3 & 2.4 & & & \\
\hline ン & 5.2 & 3.1 & 3.5 & & & & 1.8 & 1.9 & 1.2 & 5.9 & 6.3 & 5.2 \\
\hline アンモ & 1.7 & 3.3 & 3.5 & & & 0.5 & 8.6 & 14.5 & 14.2 & 12.3 & 13.8 & 16.9 \\
\hline ヒス ス $シ * y$ & 0.6 & 1.8 & 1.8 & & & & 2.7 & & 2.7 & + & 5.7 & 4.8 \\
\hline アルギニン & 20.8 & 29.6 & 39.4 & & & & 34.9 & 30.3 & 53.2 & 3.2 & 9.0 & 6.5 \\
\hline Total & 182.8 & 360.2 & 405.8 & 18.7 & 49.6 & 44.4 & 259.0 & 274.3 & 149.4 & 373.3 & 554.8 & 574.0 \\
\hline
\end{tabular}

*トマト,ニンジン, セロリ, パセリ,レモンシュース

注：表中で数値として記载されていない場合，パターン類以率の計算には0を用いた。 


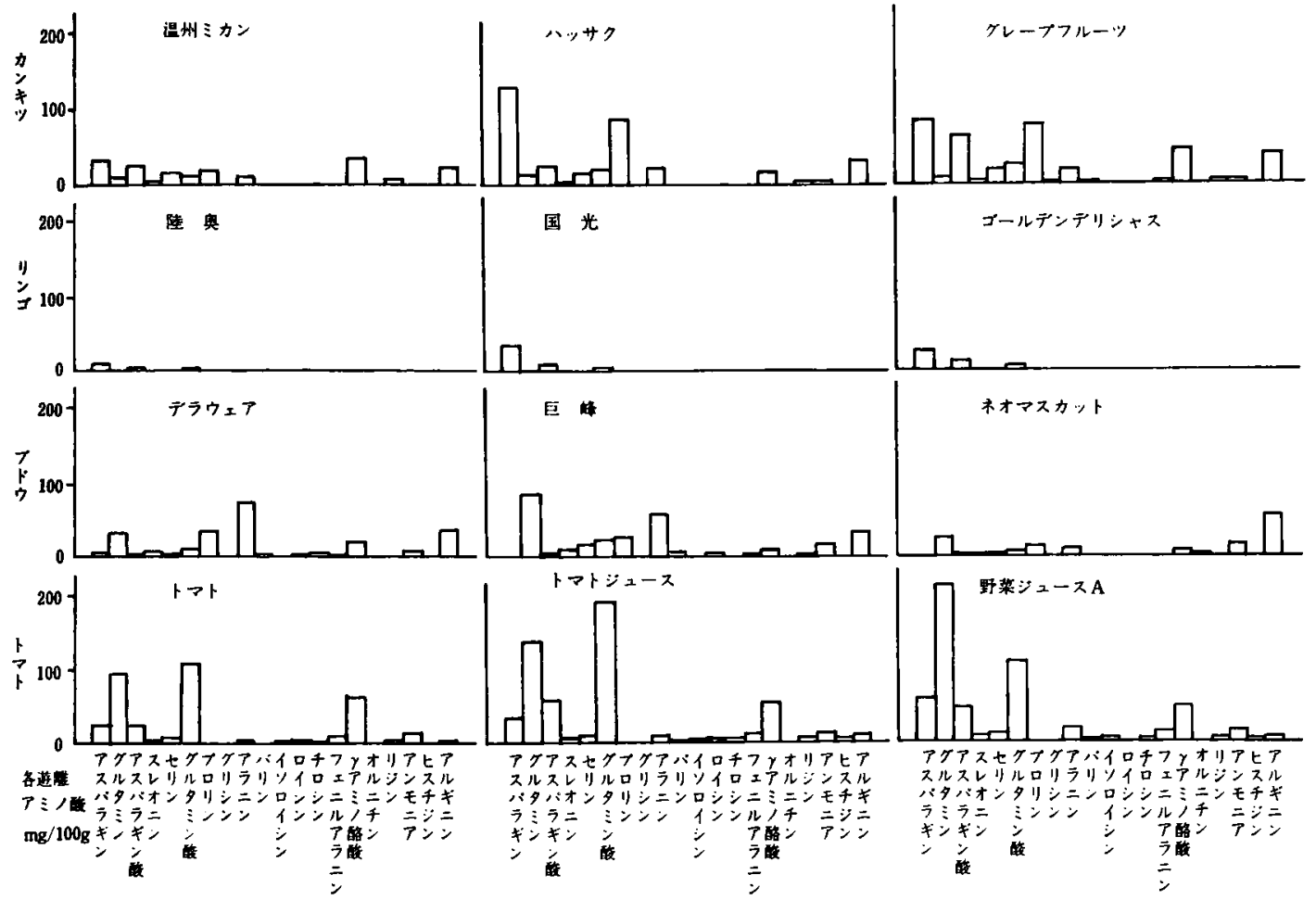

図 1 遊離フミノ酸含量ヒストグラム（果寒・野菜 12 食品）

いて空白にしてある。なお類似率は対角線の右上側と左 下僋との 2 箇所に同じ数值が記載されており，その意味 では元長なのであるが，類似率表からパーン相互間の 類似，非類似の読みとりを行なら際には，右上半部のみ よりは,この表のほうがはるかに便利なので, コンピュ ータにより計算, 打ち出しを行なわせる場合, この表の よらに打ち出させるエ夫をするのが望ましい。

さて，温州ミカンのパターンがどの食品に似ているか を知ろらといら場合は, 最初の温州ミカンの列をタテに 見ることにより，もっとす 1 に近い数值を探がせばよ い。すると，類似率 0.918 でタレーブフルーツともっと

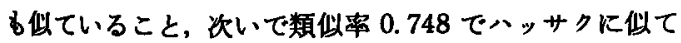
いることがわかり，やはりカンキッ類どうしは遊離てミ 八酸パーンがよく似ていることを数值の形で客観的に 示すことができる。逆に温州ミカンのパターンに似てい ないのとしては類似率が小さいるのを探すことによ ク,ブドゥの巨峰が 0.470 でもっともパターンが似てい
ないことを知ることができる。

その他の食品についても同様にしてパターンが似てい るもの，似ていないものを選び出すことができるが，こ の例の中では 12 食品全体の中で最もパターンが似てい るものはリンゴとしの中の陸奥と国光で, パターン類 似率は 0.991 であること，また最も似ていないのは，国 光とネオマスカットでありここ場合の類似率は 0.060 ときわめて低いことなどを見付け出すことができる。

次に，全体的な判断をするためには，ハターン類似率 表に並んでいる数值を, 高いものの方から,およそ $10 \%$, $20 \%, 40 \%, 20 \%, 10 \%$ という具合に分けて,色の湿淡 で表現した図を作ると便利である（図2）。

図 2 よりこの 12 食品の間では, リンゴ 3 点, トマト 関連 3 点はそれぞれパターンが似ていること，これに対 してブドゥ 3 点は似ていることは似ているが, リンゴや トマト，カンキッほどではないこと，またブドウ3点は 他の食品 9 点に対してもパターンの類似性が低いこと, 
表 2 パターン類以率表（12 食品間, 遊離了ミノ酸パターン)

\begin{tabular}{|c|c|c|c|c|c|c|c|c|c|c|c|c|c|}
\hline & \multicolumn{3}{|c|}{ カンキッ } & \multicolumn{3}{|c|}{ リ ン ゴ } & \multicolumn{3}{|c|}{ ブドウ } & \multicolumn{3}{|c|}{$卜 \quad>\quad 卜$} \\
\hline & & 温 州 & ハッサ & $\begin{array}{l}\text { グレー } \\
\text { プ } \\
\text { フルー } \\
ッ\end{array}$ & 陸 奥 & 国 光 & $\begin{array}{l}\text { ゴール } \\
\text { デン } \\
\text { デリシ } \\
\text { ヤス }\end{array}$ & $\begin{array}{l}\text { デラウ } \\
\text { ×ア }\end{array}$ & 巨 峰 & $\begin{array}{l}\text { ネオマ } \\
\text { スカッ } \\
ト\end{array}$ & トマト & $\begin{array}{l}ト マ ト \\
\forall=2- \\
x\end{array}$ & $\begin{array}{l}\text { 野 菜 } \\
\because シ 2 \\
\text { ス A }\end{array}$ \\
\hline & 温州ミカン & & .748 & .918 & .611 & .602 & .640 & .582 & .470 & .566 & .569 & .508 & .512 \\
\hline$\dot{Y}$ & 八ッ サ ク & .748 & & .899 & .817 & .815 & .798 & .431 & .310 & .373 & .292 & .287 & .346 \\
\hline $\begin{array}{l}7 \\
\cdots\end{array}$ & $\begin{array}{lll}\text { グ } & \text { フ } \\
フ & \text { プ }\end{array}$ & 18 & 899 & & .676 & 668 & .706 & .522 & .366 & .483 & .421 & 408 & .398 \\
\hline & 陸 & .611 & .817 & .676 & & .991 & .989 & .138 & .135 & .087 & .326 & .350 & .386 \\
\hline V & 国 & .602 & .815 & .668 & .991 & & .983 & .079 & .067 & .060 & .260 & .267 & .327 \\
\hline ᄀᄀ" & 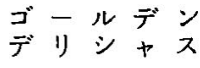 & 640 & 798 & .706 & .989 & .983 & & .088 & .068 & .082 & .329 & .360 & .368 \\
\hline ブ & デラウェア & .582 & .431 & .522 & .138 & .079 & .088 & & .855 & .699 & .412 & .384 & .459 \\
\hline$F$ & 巨 & .470 & .310 & .366 & .135 & .067 & .068 & .855 & & .690 & .616 & .595 & .770 \\
\hline ウ & ネオマスカット & .566 & .373 & .483 & .087 & .060 & .082 & .699 & .690 & & .374 & .363 & .430 \\
\hline 1 & 7 & .569 & .292 & .421 & .326 & .260 & .329 & .412 & .616 & .374 & & .974 & .915 \\
\hline 7 & トマトジュース & .508 & .287 & .408 & .350 & .267 & .360 & .384 & .595 & .363 & .974 & & .897 \\
\hline 卜 & 野菜ジュース & .512 & .346 & .398 & .386 & .327 & .368 & .459 & .770 & .430 & .915 & .897 & \\
\hline
\end{tabular}

注：すべて 1〜0の間の数值となるので小数点以下の数值で示してある。
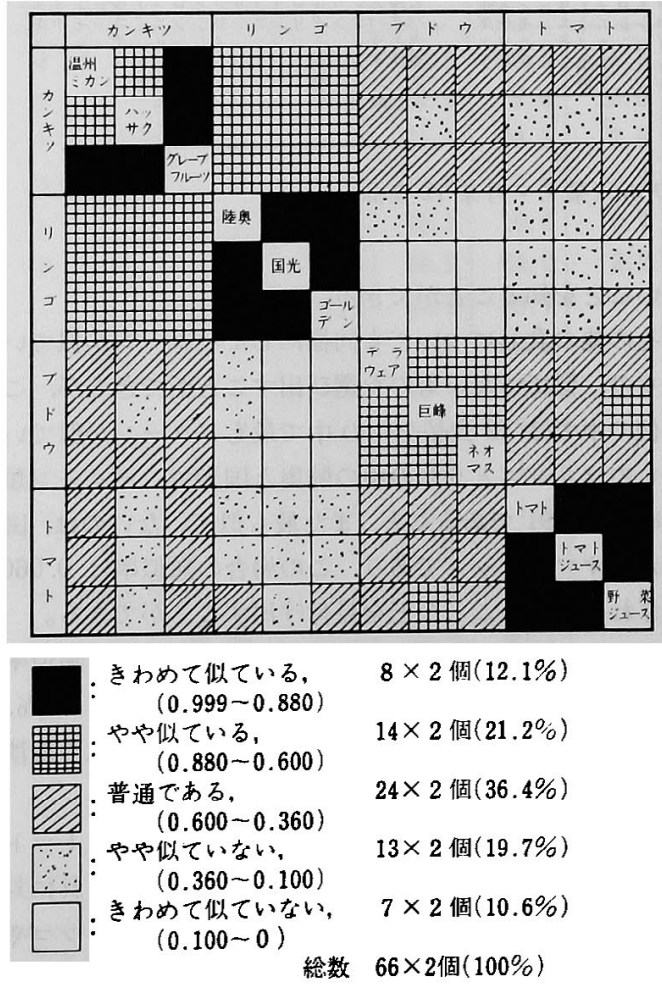

図2 ハターン類似率表の滣淡表現図
特にリンゴとの類似性がきわめて低いことなと゚を読みと ることができる。このよらな視覚的な表現手法は，測定 対象が数十点以上になる場合は特に有用である。

以上例を用いて，パターン類似率の計算が，測定対象 の鑑別，診断，分類などに有効なことを解説した。

なお分類面への応用については解説「分析值のハター ン的取り扱い」6)を参照されたいが，池田らにより葉油 40 成分のパターン類似率をカンキッ類 120 種の分類研 究へ適用する試みが行なわれている7。

またアミノ酸パターンへのパターン類似率の応用とし て, 食用キノコ類への適用 ${ }^{8)}$, ミカン果実の成育過剭へ の適用 ${ }^{9}$ が報告されている。

\section{4. 分別成分への適用例}

今までの例では，湘定値はすべて明確な化学物質の含 有量であったが，パターン類似率の計算は食品檴成粒子 の大きさ等による分別測定值などへ適用が可能である。 今井ら ${ }^{10)}$ は市肘コムギ粉扔よび国産コムギのテストミル 粉の粒度分布をコールターカウンターで測定し，それら の粒度分布ヒストグラムの類似程度をパターン類似率で 計算し，どの用途のコムギに似ているかの推定を行なっ ている。

また食品ではないが，海洋污染の原油の原産地識別の ためにゲルパーミェーションクロマトグラフィーによ 
る連続的な溶出曲線を数区間に区分し，各区間の面積を 測定值としてパターン類似率を計算し，自動判別させる

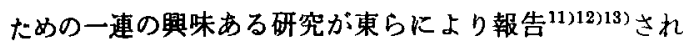
ている。

\section{5. 含有レベルが違う場合の計算}

多数の成分測定項目の中には，成分の含有レベルが著 しく違う場合がある。例えばひとつの成分は\%レベルで あるが，他の成分は ppm レベルである場合などである。 このような場合，剆定值の単位を合わせてしまらと， ppm レベルの成分の数值はきわめて小さくなり，その数 値が相対的にはかなり大きく変動したとしても，パター ン類似率の数値には計算上ほとんど影響しないという結 果になる。

このような場合には，それぞれの測定項目の平均値を 100 之する指数に各測定項目の数值を直してからハター 類似率を計算するなどの 湘定値の 前処理が有効であ
る。

説明例としてミルクとタマゴの無機成分含量の場合を 表 3, 表 4 に示した。表 3 のA表はミルク 3 点,タマゴ 3 点, 計 6 点の食品のカルシウム, 鉄, カリウム含量を 「四訂日本食品標準成分表」から転載したものであり， 表 3 の B 表は $\mathrm{A}$ 表の数做で計算したハターン類似率表で ある。A表で見れば, ミルクとタマゴの間には鉄含量に 大きな違いがあり，直感的にパターンに差があると感じ られるのであるが，B表のパターン類似率表ではそれが らまく数值として表現されていない。ミルクとタマゴの 間の類似率が全般的にきわわて高くなってしまってい る。この理由は鉄の含量が，カルシウム，カリウムに比 ベて二桁程度低く，そのため鉄含量の変動がパターン類 似率の計算にあまり影響しないためである。

そこで鉄含量の変動を対等に評価するために，カルシ ウム, 鉄, カリウムの測定值を平均含量を 100 とする指数

表 3 含有量レベルが違う場合の計算例

$\mathrm{A}:$ 無機 3 成分の含量 $(\mathrm{mg} / 100 \mathrm{~g})$

\begin{tabular}{|c|c|c|c|c|}
\hline & & $\begin{array}{l}\text { カルシ } \\
\text { ウム }\end{array}$ & 鉄 & $\begin{array}{l}\text { カリウ } \\
\text { ム }\end{array}$ \\
\hline \multirow{3}{*}{$\begin{array}{l}\vdots \\
\text { ル } \\
\text { ク }\end{array}$} & 牛 乳 & 100 & 0.1 & 150 \\
\hline & ヤギ乳 & 120 & 0.1 & 220 \\
\hline & 人乳 & 27 & 0.1 & 48 \\
\hline \multirow{3}{*}{$\begin{array}{l}\text { 夕 } \\
? \\
\text { J }\end{array}$} & けい卵 & 55 & 1.8 & 120 \\
\hline & うずら卵 & 60 & 3.0 & 150 \\
\hline & あひる卵 & 65 & 2.6 & 130 \\
\hline & F均 & 71.2 & 1.28 & 136.3 \\
\hline
\end{tabular}

「四訂日本食品標隼成分表」による
$\mathrm{B}$ ：左の A 表の数植によるパターン類似率表

\begin{tabular}{|c|c|c|c|c|c|c|c|}
\hline & & $\Sigma$ & ル & $\eta$ & \multicolumn{2}{|c|}{ 夕 } & \multirow{2}{*}{$\begin{array}{c}\text { ゴ } \\
\text { あひる }\end{array}$} \\
\hline & & 牛 乳 & ヤギ乳 & 人 乳 & けい卵 & うずら & \\
\hline \multirow{3}{*}{$\begin{array}{l}\Sigma \\
\text { ル } \\
ク\end{array}$} & 牛 乳 & & .996 & .997 & .987 & .978 & .992 \\
\hline & ヤギ乳 & .996 & & $.999^{*}$ & .997 & .993 & .999 \\
\hline & 人 乳 & .997 & $.999^{*}$ & & .997 & .991 & .999 \\
\hline \multirow{3}{*}{$\begin{array}{l}\text { g } \\
? \\
\text { J }\end{array}$} & けい卵 & .987 & .997 & .997 & & .999 & .999 \\
\hline & うずら卵 & .978 & .993 & .991 & .999 & & .997 \\
\hline & あひる卵 & .992 & .999 & .999 & .999 & .997 & \\
\hline
\end{tabular}

*.9999であるがラウンドすると1になるので.999と表陪した

表 4 含有量レベルが違う場合（表 2 ）の補正計算例

$A ：$ 無機 3 成分の各成分の 平均值を 100 とする指数

\begin{tabular}{|c|c|c|c|c|}
\hline & & $\begin{array}{l}\text { カルシ } \\
\text { ウム }\end{array}$ & 鉄 & $\begin{array}{l}\text { カリウ } \\
\text { ム }\end{array}$ \\
\hline \multirow{3}{*}{$\begin{array}{l}\Sigma \\
\text { ル } \\
\text { ク }\end{array}$} & 牛 乳 & 140.4 & 7.8 & 110.1 \\
\hline & ヤギ乳 & 168.5 & 7.8 & 161.4 \\
\hline & 人 乳 & 37.9 & 7.8 & 35.2 \\
\hline \multirow{3}{*}{$\begin{array}{l}\text { y } \\
? \\
J^{\prime}\end{array}$} & けい乳 & 77.2 & 140.6 & 88.0 \\
\hline & うずら卵 & 84.3 & 234.4 & 110.1 \\
\hline & あひる卵 & 91.3 & 203.1 & 95.4 \\
\hline & 均 & 100 & 100 & 100 \\
\hline
\end{tabular}

$\mathrm{B} ：$ 左のA表の数值によるパターン類似率表

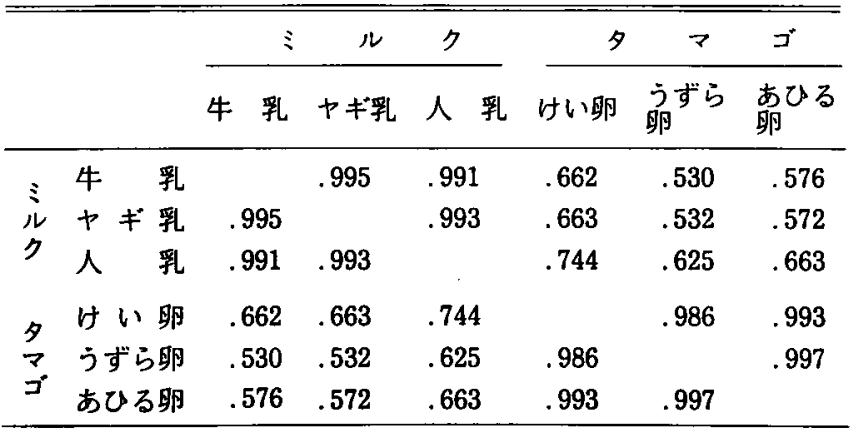


に直し，その数値を使用してパターン類似率を計算して みたのが表 4 のA表，B表である。B表ではミルク3点 間の類似率,タマゴ 3 点間の類似率が充分高く計算され ており，それに対してミルクとタマゴ間の類似率はかな り低く出ており，このA表のように測定值を指数化する ことが，含量レベルの低い成分の測定值を評価するため に有効である。

また，このよらな測定値の前処理については，標倠偏 差を単位とする数値に直すなど，種々の工夫が考えられ る。なお湘定項目の中には $\mathrm{pH}$, 色相，など成分測定値 とは本質的に異なる性質を持つ測定値が存在する。これ らの測定値は本稿で取り扱かっている意味でのパターン を構成する測定値とはいえないのであるが，それらの測 定値をむ含むパターンについても，バターン類似率の計 算はある程度の有効性を持つるのと考学られる。もちろ んそれぞれの特殊条件の中での充分な注意が必要であ る。

\section{6. 平均パターン}

測定対象を数回測定すれば，そのたびに多少连ら測定 值が得られる。したがって多少違ら数值群パターンが得 られる。この場合あるいはそれ以外でも一般にパターン の平均を求める必要が生ずる。パターン類似率で考兄れ ば，平均パターンと各回測定パターンとの閒の類似率の 和が最大になるよ5に平均パターンを定めるのが望まし い。あるいは, パターン間距離 $(\theta)$ の総和を最少にする よらなパターンである。

今, 平均パターンを求める必要上, 測定值群のベクト ル $\overrightarrow{O A}$ と方向が同しでべトルの長さが1となるよら に縮少（执大）しだ゚クトル

$$
\mu_{A}=\frac{1}{\overrightarrow{\mid O A} \mid}\left(\begin{array}{c}
a_{1} \\
a_{2} \\
\vdots \\
a_{n}
\end{array}\right)=\sqrt{\sum_{i=1}^{n} a_{i}^{2}}\left(\begin{array}{c}
a_{1} \\
a_{2} \\
\vdots \\
a_{n}
\end{array}\right)=\left(\begin{array}{c}
\mu_{A 1} \\
\mu_{A 2} \\
\vdots \\
\mu_{A n}
\end{array}\right)
$$

ただし

$\mu_{A i}:$ ベクトル $\mu_{A}$ の第 $i$ 要素 $=a_{i} /|\overrightarrow{O A}|$ を成分パターンベクトル（以下成分バターンと呼ふ）と 定義する。これは $\mathrm{n}$ 次元ニークシッド空間で, 原点を 中心とする半径 1 の $n-1$ 次元超球面上の点になる。すな わち今まで $\mathrm{n}$ 個の数値からなる数値群 $\mathrm{A} ;\left(a_{1}, a_{2}, \ldots\right.$, $a_{n}$ ) のパターンを $\mathrm{n}$ 次元空間の位直ベクトルの方向と 考えていたか，これは $\mathrm{n}-1$ 次元球面上の位置として考 えるとらえ方である。

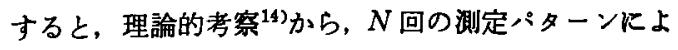
る平均成分パターン $\bar{\mu}$ は

$$
\bar{\mu}=\frac{1}{\sqrt{\sum_{i=1}^{n}\left(\sum_{l=1}^{N} \mu_{l i}\right)^{2}}}\left(\begin{array}{c}
\sum_{i=1}^{N} \mu_{l 1} \\
\sum_{i=1}^{N} \mu_{l 2} \\
\vdots \\
\sum_{l=1}^{N} \mu_{l n}
\end{array}\right)
$$

ただし， $\mu_{l i}$ ：第 $l$ 番の湘定値群の成分バターンベクト ルの第 $i$ 要素 $(l=1,2, \ldots, N, i=1,2, \ldots, n)$ とな る。

なお，成分パターンのとらえ方，つまり n-1 次元球面 上の点としてパターンを考えるとらえすは視覚的になし みやすい。したがって単位球面上の直線距離であるバタ ーン間距離 $(\theta$, ラージァン)をパターン類似率 $(\cos \theta)$ から逆算し，この球面距離を用いて，研究対象間の位貫 関係の見取図などを作ることができる゙。

\section{7. パターン類似率の要因解析}

一般にパターン類似率が高く（1に近い）計算される 場合は，すへての要因がパターンを類似させる方向に㮣 いていると考えられる。一方・ターン類似率が低く計算 される場合は，バターンを構成している要因のどれかが パターン類似率を低くする方向に働いていると想定され る。このような場合にどの要因が類似率を低くしている かは, 各要因を除いてパターン類似率を計算することに よって知ることができる。このような計算法を隇次パタ ーン類似事（以前は減数類似率々呼んでいたが， $\mathrm{n}$ 次元 空間の計算を n-1 次元空間の計算に下げることになる ので今回からこのよらに呼ら゙)といら。

隇次類似率は $\mathrm{n}$ 個の成分, $X_{1}, X_{2}, \ldots X_{n}$ の測定值か らなるパターン $A ;\left(a_{1}, a_{2}, \ldots, a_{n}\right)$ とパターン $B ;\left(b_{1}\right.$, $\left.b_{2}, \ldots, b_{n}\right)$ とがある場合に成分 $X$ ，を除いて計算した 類似率であり，いま $-x_{r} S_{(A, B)}$ とかくとすると

$$
-x_{r} S_{(A, B)}=\frac{\sum_{i=1}^{n} a_{i} b_{i}-a_{r} b_{r}}{\sqrt{\sum_{i=1}^{n} a_{i}^{2}-a_{r}^{2}} \sqrt{\sum_{i=1}^{n} b_{i}^{2}-b_{r}^{2}}}
$$

で計算される。第 3 節の表 2 によれば，ブドウのデラウ エフとネオマスカットはパターン類似率が 0.698 で同し ブドゥであるにもかかわらずかなり低い。

これについて，数種の主要遊離つミノ酸を除いた場合 の減次類似率を計算すると表 5 のよ5になる。この表か らフラニンを除いたときの隇次類似率, ーフラニンS (デラウェア、マスカット)が 0.858 ともとの類仙率 0.698 よりかなり高くなることがわかる。次いで丁ルギ 
表 5 減次類似率 $-\mathrm{x}_{\mathrm{r}} \mathrm{S}_{\mathrm{A}, \mathrm{B})}$

\begin{tabular}{|c|c|c|}
\hline & 減次類似率 \\
\hline & & デラウェア〜ネオマスカット \\
\hline & ーグルタミン & .656 \\
\hline & ープロリン & .682 \\
\hline た & $-ア \bar{\gamma}=ン$ & .858 \\
\hline 畜 & - rアミノ酪酸 & .693 \\
\hline & ーアルギニン & .788 \\
\hline & もとの類似率 & .698 \\
\hline
\end{tabular}

ンンを除いた場合が 0.788 でやや高くなり，その他のグ ルタミン,プロリン，てアミノ酪酸を除いた場合は，む との類似率とあまりかわらない。これらの数值は，表 1 すしくは図1のヒストクラムから，デラウェフのアラニ ン含量がネオマスカットよりはるかに高いこと，またて ミ，酸総量がデラウェアの力が多いにもかかわらず， フ ルギニン含量が低いことなどに対応しており，それらの 要因がハィターン類似率を低くする要因になっていること を数値的に示している。

\section{8. 答別面への応用}

食品の鑑別にも諸種の場合がある。生物種の鑑別，品 種の箈別，生産地の鑑別，生産法の鑑別，加工食品の原 料の監別，原料配合割合の篮別，生産時点の鑑別などで ある。

食品の鑑別についてのパターン類似率の応用一般につ

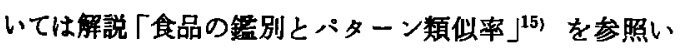
ただくとして，ここでは辆出入規制と関連して教類食品 の原料を㘕別した実例と，今後益々重要になると考えら れる加工食品の原料配合割合の推定について述べる。

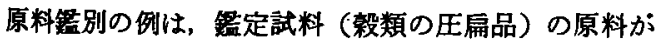
コムギ,トリティカーレ(ライコムギ),ライムギのどれ
であるか,というものである。

鑑定試料ならびに比較のための参考試料につき精密な 総丁ミノ酸組成の分析を行ない，パターン類似率表を作 成し（表 6: 鉿木忠直ら：未発表）, 右端の鑑定試料の類 似率の数值がもっとも高くなる（0.9990）ライコムギで あろらと鑑定した。一般に蛋白質のアミノ酸組成はきわ めて安定性の高いものであるから，遊離アミノ酸含量の 少ない食品，款類，豆類などの加工食品の鑑別には総了 ミノ酸パターンのパターン類似率の計算は有効な手法と い光よう。

次に加工食品の原料配合割合を推定する手法について のべる。

ある加工食品 $Z$ か，原料食品 $A, B, \ldots, M$ の混 合によって作られ，その過程において成分の破壊などの 変化がないものとする。また $A, B, \ldots, M$, したが って $Z$ \& $n$ 個の成分のみから構成されていると仮定す る（\%表示であれば加え合わせると 100 になるとの仮 定)。

今「6. 平均パターン」の節で定義した成分パターン （大きさ1の成分パターンペクトル）を考えると，混合 食品 $Z$ の成分バターン, $\mu_{Z}$ は

$$
\mu_{Z}=w_{A} \mu_{A}+w_{B} \mu_{B}+\ldots+w_{M} \mu_{M}
$$

ただし $w_{A}: Z$ の成分パターンを合成する上で，原料食 品 $A$ の成分バターンが寄与する度合， $\mu_{A}$ ：原料食品 $A$ の成分パターン, $w_{B}, \mu_{B}$ などす以下同様 で表わされる。

混合食品の成分パターンと原料の成分パターン（また は平均成分パターン) から原料の配合割合を求めようと いら場合，実漈の測定では測定誤差を避けられないし， また原料の種類しか知らない場合は，その平均成分パタ ーンと実際に用いられた原料の成分パターンには違いが ある。したがって前式において，実際には等号は成立せ ず，右辺に誤差ベクトル€を入れる必要がある。この誤

表 6 鑑別の実例（アミノ酸パターンによる）

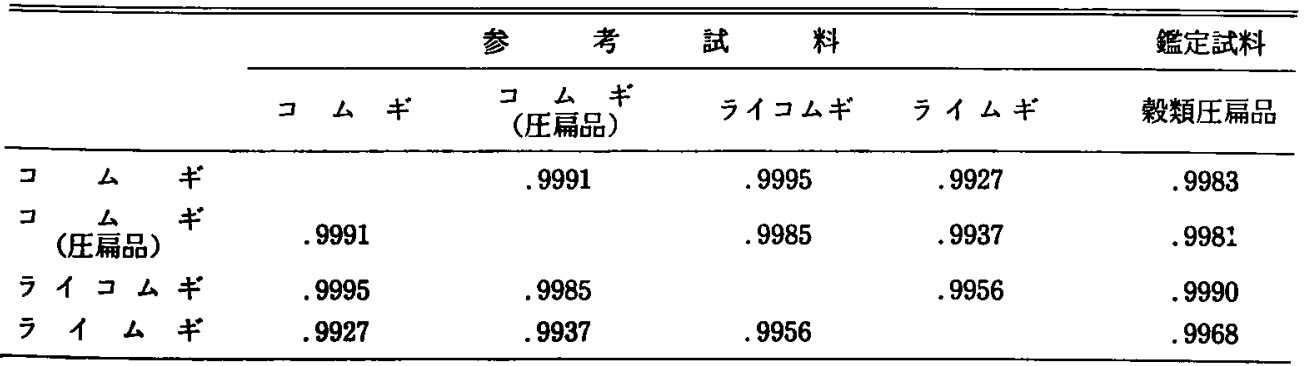


差ベクトル€の絶対値を最少にするよらに, $w_{A} \sim w_{M}$ を 求めると行列の記号で次式が得られる ${ }^{14)}$ 。

$$
\begin{aligned}
& w=\left(\begin{array}{c}
w_{A} \\
w_{B} \\
\vdots \\
w_{M}
\end{array}\right)=\left(P^{\prime} P\right)^{-1} P^{\prime} \mu_{Z}
\end{aligned}
$$

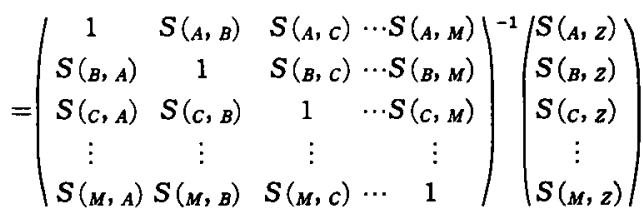

たたし，P: 原料食品の成分八

$$
\begin{aligned}
& \text { 原料食品の成分パ } \\
& \text { 食品 } A \sim M \text { の順 } \\
& \text { に並べた行列 }
\end{aligned}=\left(\begin{array}{cccc}
\mu_{A 1} & \mu_{B 1} \cdots & \mu_{M 1} \\
\mu_{A 2} & \mu_{B 1} \cdots & \mu_{M 2} \\
\vdots & \vdots & & \vdots \\
\mu_{A n} & \mu_{B n} \cdots & \mu_{M n}
\end{array}\right)
$$

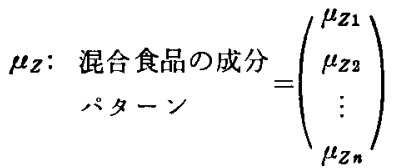

$S(A, B)$ ：食品 $A$ と食品 $B$ のバターン類似率 $=S(B, A)$, 以下同様

このよらな重みで合成される成分ハターンは, 混合製 品の成分パターンとのハターン類似率がもっとも大きな ものとなる。

ところでこここで得られた重みは成分バターン合成の ための重みであって, 原料配合そのるのの重みではな い。原料配合の重みを $q_{A} \sim q_{M}$ とすれぱ，その比率は

$$
q_{A}: q_{B}: \cdots: q_{M}=\left(\sum_{i=1}^{n} \mu_{A i}\right) w_{A}:\left(\sum_{i=1}^{n} \mu_{B i}\right) w_{B}: \cdots:
$$

$$
\left(\sum_{i=1}^{n} \mu_{M i}\right) w_{M}
$$

で与えられる。

な技，最初の仮定「原料食品も混合食品も $n$ 個の成分 のみから構成される」を満足しない場合には， $n$ 個の成 分の総量とその他の成分の総量との比率から補正計算を することにより実際の原料配合を推定することができ る。

この項については文献 ${ }^{(4)}$, 解説2)を参照されたい。 もっとも簡単な 2 つ原料 A, B から混合食品 Z か 作られている場合の成分パターンの 合成に関しては, $S_{(A, B)}=S_{(B, A)}$ なので

$$
\begin{aligned}
& w=\left(\begin{array}{c}
w_{A} \\
w_{B}
\end{array}\right)=\left(\begin{array}{cc}
1 & S\left({ }_{A}, B\right) \\
S(B, A) & 1
\end{array}\right)^{-1}\left(\begin{array}{l}
S(A, Z) \\
S(B, Z)
\end{array}\right) \\
& =\frac{1}{1-S(A, B)^{2}}\left(\begin{array}{cc}
1 & -S\left({ }_{A}, B\right) \\
-S(A, B) & 1
\end{array}\right)\left(\begin{array}{l}
S(A, Z) \\
S(B, Z)
\end{array}\right) \\
& =\frac{1}{1-S_{(A, B)}{ }^{2}}\left(\begin{array}{l}
S(A, Z)-S(A, B) S\left({ }_{B}, Z\right) \\
S(B, Z)-S(A, B) S(A, Z)
\end{array}\right)
\end{aligned}
$$

したがってウェイト $w_{A}$ と $w_{B}$ の比率は

$w_{A}: w_{B}=S(A, z)-S\left({ }_{A}, B\right) S\left({ }_{B}, z\right): S\left({ }_{B}, z\right)$

$$
-S\left({ }_{A}, B\right) S(A, Z)
$$

$=[\dot{A} \zeta Z$ の類似率 $]-[A$ $[B$ 類似率 $]$

$\times[B$ と $Z$ の類似率 $]:[B$ と $Z$ の類似率 $]$

$-[A と B$ との類似率 $] \times[A と Z$ 類似率 $]$

となり, 理論的にはバターン類似率から簡単に計算でき る。

\section{9. パターン類似率と相関係数}

パターン類似率はその他食生活の研究などの調查研究

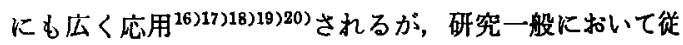
来広範囲に利用されている相関係数との関係について説 明しておこう。

今, 測定対象 $N$ 個, 測定項目 $n$ 個の測定値からなる マトリックスがあるとしよう。3節の実例でいえば, 測 定対象は $N=12$ 個の果実・野菜であり, 測定項目は $n$ =20 個の各種遊離アミノ酸といらことになる。

これらのデータ・マトリックスを表記する場合に，測 定対象を $A, B, C \cdots$ として測定項目を $1,2,3 \cdots \cdots$ とす れば，表 7 の 表のよらになり，逆に測定対象を 1， $2,3, \cdots \cdots$ として湘定項目を $A ， B ， C$ とすれば表 5 の $\mathrm{B}$ 表のよらになる。A 表と B 表とは内容は全く同しであ る（B表の方には各測定項目の平均を付加してあるが）。 パターン類似率の方は $A$ 表の表記を用いて, 測定対象 $A$ と $B$ とのパターン類似率 $S(A, B)$ は

$$
S(A, B)=\frac{\sum_{i=1}^{n} a_{i} b_{i}}{\sqrt{\sum_{i=1}^{n} a_{i}^{2}} \sqrt{\sum_{i=1}^{n} b_{i}^{2}}}
$$

で計算される。

これに対して，相関係数の方はB表の表記を用いて， 測定項目 $A$ と $B$ との相関係数, $r(A, B)$ は

$$
r(A, B)=\frac{\sum_{I=1}^{N}\left(a_{I}-\bar{a}\right)\left(b_{I}-\bar{b}\right)}{\sqrt{\sum_{I=1}^{N}\left(a_{I}-\bar{a}\right)^{2}} \sqrt{\sum_{I=1}^{N}\left(b_{I}-\bar{b}\right)^{2}}}
$$

で計算される。 
表 7 パターン類似率と相関保数の訃算法の説明表

$\mathrm{A} ：$ パターン類似率の場合

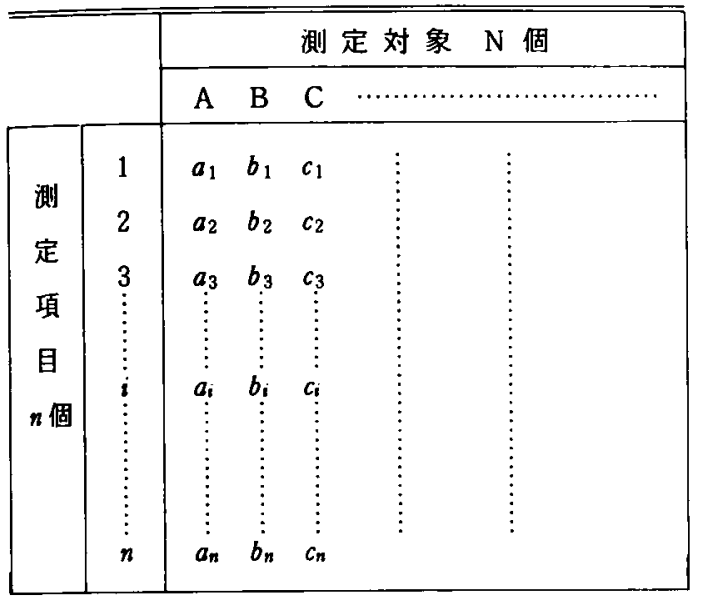

パターン類似率 $\left(S_{(A, B)}\right)$

$=\frac{\sum_{i=1}^{n} a_{i} b_{i}}{\sqrt{\sum_{i=1}^{n} a_{i}^{2}} \sqrt{\sum_{i=1}^{n} b_{i}^{2}}}$

数式自体は，相関俰数の方か，各測定值から平圴値を 引いている以外は型式としては同様である。つまり相関 保数の方は，B表にしたがっていかば横に計算してお。 $\eta$, 測定項目の方を $A ， B$ に固定し，測定対象を $1 ， 2$, $3 ， \ldots$ と㮌次入れ替えて計算することにより，測定対象 仕唅象されて, 特定測定項目, 2 種の間の関保が相関釈 数として得られるのである。

これに对し，゚ターン類似率の方はA表にしたがって いかば維に計算するのであり，測定対象の方を A，B K 固定し，測定項目の方を $1 ， 2 ， 3 ， \cdots$ と㮌次入れ替えて 計算することにより，測定項目は捨象されて，特定測定 対象 2 種の間の関係がハターン類似率として得られるの である。

相関俰数の方では各測定値から平均値を引いているた め,成分測定の上5に測定值がすべてブラスの場合でも， 共分散がマイナスになることがあるので，プラス1から マイナス1の範囲の計算值が得られる。これに対しハタ ーン類似率の方は，平均値を引くといら計算をしないた めに (ハターンをべクトルの方向と考えているためであ る), 通常ブラス 1 から0までの計算値が 得られるので ある。

一般に研究を行なら場合には，測定項目間の関保を考 えることと共に，測定対象間の関係を考えることが重要
$\mathrm{B} ：$ 相関係数の場合

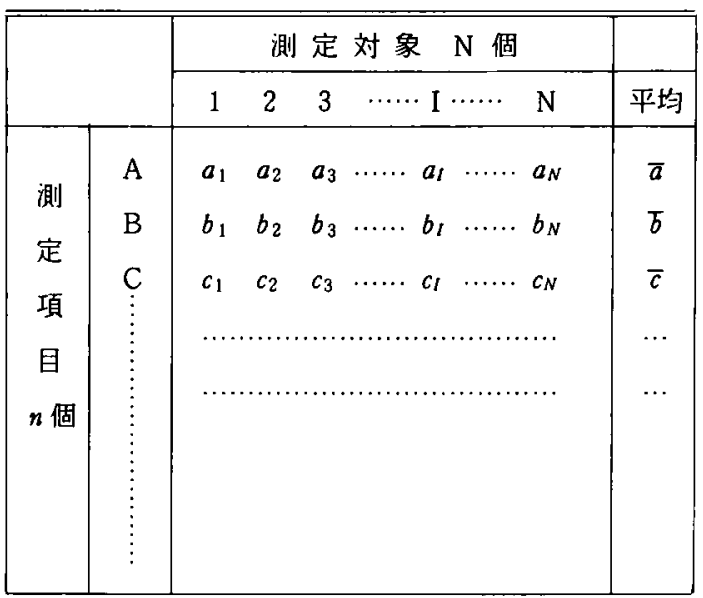

相関係数 $(r(A, B))$

$=\frac{\sum_{I=1}^{N}\left(a_{I}-\bar{a}\right)\left(b_{I}-\bar{b}\right)}{\sqrt{\sum_{t=1}^{N}\left(a_{I}-\bar{a}\right)^{2}} \sqrt{\sum_{t=1}^{N}\left(b_{I}-\bar{b}\right)^{2}}}$

である。測定対象間のバターンの類似性を数值計算で示 す一手法としてのハターン類似率の応用面がその点にあ ると考えている。

$$
\text { 文献 }
$$

1）田村真八郎・大沢交江: 夈養と食糧, 22, 493(1969).

2)松永隆司・田村真八郎:化学と生物, 20, 675(1982).

3) 由村真八郎・石間紀男 - 大讯交江 - 吉川誠次：液 体クロマトグラフ研究会䍀演要旨集 No. 10, p. 20 (1968).

4）鈴梠忠值 - 栗原的美子 - 田村真八郎：食品総合研 究所報告 31，42(1976).

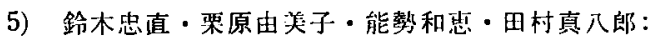
食品総合破究所報告, 32, 80 (1977).

6) 田村真八郎： ゙゙しせき, 1978 年 (6 号), 379(1978).

7) 池田 勇 -小林省䋗：果樹試験場安芸津支場試験 研究年報（昭和 56 年度 No. 10), p. 21 (1982).

8)阿部宏喜・後藤砂智子・青山昌照: 栄䈍と食糧, 33, 177 (1980).

9) 柴出 萬 - 鉿术忠直 - 岩切徹 - 江口 浩 - 中原 美智男：九州農業研究，42，205 (1980).

10) 今井 徹ら：昭和 59 年度食品試験研究成綪・計画 概要集（食品総合研究所），p. 33 (1985).

11) 東 国茂・萩原一芳：分析化学，30，785 (1981).

12) 東 国茂・萩原一芳：分析化学, 31. 494 (1982).

13）東 国茂・萩原一芳：分析化学，33，68 (1984).

14）松永隆司・鈴木柋直・出村真八郎：食品総合砵究 
所報告，35，96(1979).

15）田村真八郎：化学々生物，17，34（1979）.

16）田村真八郎 - 石間紀男 -大沢交江 - 吉川誠次：栄 養と食糧，22，560 (1969).

17)岡田玲子：栄意と食糧，26，191（1973）.

18）丸井英二・豊川裕之：日本公衆衛生学会誌, 22,
385 (1975).

19）田村真八郎 - 栗原由美子：食品総合研究所報告, 28, 100 (1975).

20）田村真八郎：食糧管理月報，23，No. 11， p. 11 (1971).

（昭和 60 年 8 月 27 日受理） 